\title{
Individual agency and changing language education policy in China: Reactions to the new "Guidelines on College English Teaching"
}

\begin{abstract}
Cooper's (1989) LPP framework focuses on "who" the policy planner is and "who" implements the policy to "whom". These are particularly significant factors in a highly centralized education system such as China's, where the effect of different individuals as actors in LPP remains largely unexplored. This article examines the controversy around the predominant status of College English and the resulting adjustments that have been made in a new English education policy — Guidelines on College English Teaching (GCET) — in 2017, and categorizes the relevant stakeholders into five groups from macro to micro levels and examines their agency roles through investigating their attitudes, interpretations and reactions towards the change in the status of College English in the GCET. The results show that multiple layers of individuals have been endowed with disproportionate powers in status planning. Compared with English teachers and people with expertise, people with influence in society and university administrators constitute the more powerful forces in effecting language policy making.
\end{abstract}

Keywords: Status of College English in China; individual agency; language education policy; CECR; GCET

\section{Introduction}

"Who does what to whom" is a well-known framework for Cooper's (1989) language planning and policy (LPP) scheme (Kaplan \& Baldauf 1997, p. 28). Individuals and their roles in national, institutional and interpersonal levels largely determine the process of policy making, implementation and outcomes of LPP. Consequently individual agency has received much attention in recent studies, especially with regard to micro-level planning (e.g. Baldauf, 2008; Baldauf \& Kaplan, 2003; Canagarajah, 2005; Hornberger \& Johnson, 2007; Liddicoat, 2019; Johnson \& Johnson, 2015; Ricento, 2000; Wiley \& Garcia, 2016; Zhao \& Baldauf, 2012). Agency, according to Ricento (2000, p. 206), is the distinctive feature of "newer critical/postmodern [approaches], i.e. the role(s) of individuals and collectives in the processes of language use, attitudes and ultimately policies." A focus on agency involves exploration of the locations of acceptance, resistance and interpreting and shaping educational policy at the grassroots level (Hornberger \& Johnson, 2007), as attitudes, interpretation and reactions of individuals constitute effective LPP agency.

The present study focuses on foreign language education policy in China, especially English language teaching at the tertiary level. As China is the largest English education market in the world, any change in the policy on English education will have a widespread influence on millions of people, including English learners and a wide variety of interested individuals such as scholars, university administrators and teachers, etc., whose attitudes, interpretation and reactions, in turn, will have a fundamental effect on LPP making, implementation and outcomes. The investigation into individual agency at multiple levels in LPP is particularly meaningful and imperative in China. China has a highly centralized education system where policy making remains quite top-down (Shao \& Gao, 2019), and the Chinese meaning of "policy" itself also confines agency to macro level 
governmental resolution $(\mathrm{Li}, 2016)$. In these circumstances, previous LPP studies in China were mainly focused on the interpretation and analysis of top-down policies (Hu, 2007; Lu, 2003), and the research on local-level or bottom-up individual agency is scarce. Who has agency, how much and what sort of impact individuals have on LPP remain under-explored (Cheng, 2015). This paper aims to explore the roles of different individual agencies from macro to meso and micro level and their impact on LPP in China through investigating the attitudes, interpretation and reaction of multiple levels of individuals towards the status of College English, a main compulsory course for almost all non-English majors in universities in China.

\section{Brief introduction to individual agency in LPP}

In the early 1960s, the predominant LPP models tended to focus on large-scale planning and national policies, usually undertaken by the government, and the dominant LPP theories have viewed the disciplines as the organized pursuit of solutions to language problems through top-down activities, usually at national level (Fishman, 1973; Jernudd 1973; Rubin \& Jernudd, 1971). Since the 1990s, a flood of immigrants to developed nations has triggered critical language planning (CLP) and recently a post-structural/post-modern approach, which has moved the research on LPP beyond the traditional top-down research model to a multi-layered view of policy making (Hornberger, 2006; Kaplan \& Baldauf, 1997, 2003; Liddicoat \& Baldauf, 2008; Ramanathan, 2005; Ricento \& Hornberger, 1996; Tollefson, 2002). "Who" has the power to influence the multi-layered LPP situations, and the role of individuals as actors in LPP and their categorization, are receiving more attention (e.g. Baldauf, 2008; Baldauf \& Kaplan, 2003; Kaplan \& Baldauf, 1997; Zhao, 2011; Zhao \& Baldauf, 2012). Kaplan and Baldauf (2003) contend that macro, meso and micro levels of LPP are on a continuum. Both top-down and bottom-up processes across national, institutional, and interpersonal layers are characterized as the metaphorical LPP onion (Hornberger \& Johnson, 2007; Ricento \& Hornberger, 1996).

As a sub-discipline of LPP, language education policy (LEP) plays an important role in the way a society articulates and plans for the futures of its members. It is relevant to all dimensions of education, from the national scale to the classroom scale and from primary education through university (Hult, 2014, 2018). In LEP, the status of the target language vis-à-vis other languages in the classroom continues to be a central issue (Hult, 2018; Kaplan \& Baldauf, 1997, 2003; Y. Li, 2010).

\section{Individual agency in foreign language education policy in China}

In China, the Ministry of Education (MOE) normally acts as an authoritative governmental agency to enact nation-wide education policy, and some distinguished scholars would be invited to participate in the enactment and interpretation of policy. In addition, people with expertise and people with influence in society are also believed to have agency at the macro level in a productive capacity in the Chinese LPP situation (Zhao \& Baldauf, 2012, p. 6). Their attitudes towards policy normally appear in the public media or in academic journals, which have a broad influence on the judgment of both the government and the general public. People with expertise and people with influence in society therefore have constituted a limited but still noticeable force in effecting government policy at the macro level in China (Zhao \& Baldauf, 2012).

At the meso to micro levels, local policy makers and implementers also play a key role in LPP (Davis \& Phyak, 2017; Garcia \& Menken, 2010; Wiley \& Garcia, 2016; Zhu \& Li, 2014). In fact, it 
is these individuals who organize the implementation of policy, seek responses to local needs and in turn influence the trend in prospective policy making (Liddicoat \& Taylor-Leech, 2014, p. 237). As the link between LPP at the national level and policy implementation in the classroom, mesolevel university administrators are key not only in negotiating and reinterpreting top-down policy, but also in making school-based LPP (Harklau \& Yang, 2019; Soler \& Vihman, 2017; Miranda et al., 2016; Pinto \& Araújo, 2019). They are in fact the real local policy arbiters and policy makers with a disproportionate amount of impact on language policy and education programs (Johnson, 2013; Johnson \& Johnson, 2015). In China, researchers have long neglected the fact that university administrators have a significant impact on LPP. For example, the policy that all non-English majors must pass the College English Test - Band 4 (CET-4) to get a diploma in the 1990s was a meso-level policy made by top leaders in various universities, not by the government. In recent decades, universities in China have been granted increasingly autonomous power to develop their own English education policy (Wang, 2015, 2016). But what their attitudes and interpretation are towards macro-level policies, and questions of what adjustment and how much impact they can produce in policy making and implementation, remain under-explored in China.

Compared with meso-level institution agency, teachers, who are the real implementers and micro policy makers in the classroom (Baldauf, 2006), play a central role as LPP agents. They have been the focus of numerous recent empirical studies, which reveal that teachers' beliefs and professional abilities, how they interpret and implement or (re)create policy, and what the policy context is, can together decide the effect and effectiveness of a language education policy (e.g. Aizawa \& Rose, 2018; Canagarajah, 2012; Hao, 2018; Hult, 2017; Johnson 2018; Liddicoat, 2014, 2019; Liddicoat \& Baldauf, 2008; Nguyen \& Bui, 2016; Ricento \& Hornberger, 1996; Yan, 2012). Even in a highly centralized system with a rigid curriculum allowing little flexibility, teachers still play a central role in policy implementation and even micro policy accommodation and resistance (Shohamy, 2010). However, English teachers in China are regarded as not yet able to play a role in education policy making (M. Li, 2010).

Following the onion metaphor (Ricento \& Hornberger,1996) and multi-level LPP theory (Kaplan $\&$ Baldauf, 2003), together with the categorization models of interest groups schematized by Zhao \& Baldauf (2012), and Wiley \& Garcia (2016), we have divided the individual players into five groups as having agency from macro to micro levels, and investigate their impact on LPP by collecting their attitudes, interpretation of and reactions to a specific foreign language education policy in China. These groups are:

Policy makers: Ministry of Education (MOE) in China. This group includes the distinguished scholars who participate in the enactment and interpretation of the language education policies;

People with expertise: This refers to the foreign language teaching and research circle in China. People in this circle are mostly (applied) linguists, scholars majoring in foreign languages and literature, translators, and English language education specialists. Most of them belong to the higher stratum of the intellectual elite (Zhao \& Baldauf, 2012, p.6);

People with influence in society: These are traditional social elites, including people with social influence because of their knowledge or their contribution to society. These people include, but are not limited to, distinguished writers, business leaders, civil rights lawyers, or ad hoc groups of lobbyists (Zhao \& Baldauf, 2012, p.6), and distinguished scholars and scientists in fields other than foreign language teaching and research;

The above three groups constitute macro-level agents. 
People with power at the meso level: These refer to university administrators, including presidents, provosts and deans of various schools;

People as implementers and micro policy makers: These are College English teachers in universities.

\section{The change in the status of College English in China}

In China, the status of English is closely related to the changing socio-political context and its role in boosting economic development. This can be seen from the following stages of development of English education at the tertiary level:

1978-1990: In 1978, after the Cultural Revolution, China began to change its foreign policy and opened its doors to the rest of the world. Soon, the importance of English as the key tool to gaining access to advanced technology and economic development was acknowledged fully, from the government to the general public. To strengthen communication with the world outside China, English became the priority foreign language in the education system (Zheng \& Davison, 2008), especially College English, a compulsory course for all non-English majors in universities.

1990s-2000s: After a decade of development at an unprecedentedly fast rate since 1978, China has sustained an average 8\% GDP growth annually. Under the circumstances, the importance of English was emphasized even further. In universities, all non-English majors had to pass CET-4 to get their bachelor's degree, and some universities even required their postgraduates to pass CET- 6 for entry into master's degree programs. In the workplace, promotion could not be attained without the corresponding English test being passed (Feng, 2009; Gil, 2016). In 2007, China overtook Germany and became the third biggest economy in the world, and the 2008 Beijing Olympic Games were also coming. Accordingly, the continual passion, from government to an enthusiastic public, for English as a crucial communicative tool engendered an influential language education policy issued by the MOE: The College English Curriculum Requirement (CECR). In this document, it was proposed that College English should be a compulsory course for all non-English majors for two full years. During this time, the full embrace of English was encouraged in various aspects such as the economy, education, culture and academia. The status of English reached a strikingly high position both in the Chinese education system and the workplace, with 400 million people (almost one third of China's population) learning English. Gradually, this phenomenon of "English Mania" began to cause great concern in academia, government and the general public (Gil, 2016, p. 61).

2010-present: In 2010, China overtook Japan to become the world's second biggest economy and was regarded as the world's economic engine. However, the growth rate of the economy immediately began to slow down. In the meantime, the feverish passion for English seemed to recede gradually at the macro level. Both government and academia began to reflect on the unintended outcome brought by English mania. Although English has always been regarded as a priority in foreign language education, the status of College English as a compulsory course for all non-English majors was always under serious question. In fact, the government has never issued this policy, so English in fact had no legal status in the Chinese education system (Gil \& Adamson, 2011; Wang, 2013). Since 2010, the mandatory regulation that students could not earn diplomas without passing CET-4 has been quietly canceled in one university after another.

During the last stage, College English was faced with unprecedented pressure from the public. On the one hand, its obviously higher status than the Chinese language has recently aroused popular 
suspicion, and even hatred, in Chinese society. In 2014, Renmin University announced that Chinese would be converted from a compulsory course to an optional one. This decision triggered widespread public outcry. On the other hand, the continuous pedagogic reform seemed not to have been successful enough to improve Chinese learners' English levels. English education in China has always been regarded as time-consuming and inefficient. In the EF English Proficiency Index (2018), China was ranked 47th in 2018. With its ranking of 36 in 2017, 39 in 2016, and 47 in 2015, China is clearly falling behind its neighbors, e.g. India, Vietnam, South Korea, etc., in English language proficiency levels. This indicates that English mania did not make much of a difference in improving English proficiency in China.

Because of the intermittent heated controversy around the status of College English and popular dissatisfaction with its low efficiency/effectiveness/effects, ten years after the CECR (2007) was issued, the MOE drafted a new language education policy for College English, i.e. The Guidelines on College English Teaching (GCET) in 2015, then issued it officially in 2017. Compared with the CECR in 2007, one of the most distinctive features of the GCET is that the status of College English is not as predominant as it was in the CECR.

\section{The study}

\section{Research questions and methodology}

In examining the changes in the status of College English in the GCET, this study aimed to explore the following research questions:

1. What is the ideological stance behind the discourse of the GCET?

2. What are the attitudes or reactions of different individuals towards the policy change?

3. What sort of impact, and how much, does different individual agency have on LPP?

To assess the different levels of individual agency in relation to the change in English LPP in China, we adopted multiple approaches to collecting data. Discourse analysis of the GCET and CECR and a review of existing studies of the attitudes and reactions of people with expertise and people with influence in society were used for the macro-level; interviews and questionnaires were used to collect the attitudes, interpretations and reactions from university administrators and College English teachers for the meso and micro levels.

\section{Setting and participants}

We chose a polytechnic university in Beijing - Beijing Information Science and Technology University (BISTU) — as the setting to study the meso to micro level individuals' attitudes and reactions towards the change in the status of College English in the GCET. BISTU is the university where the first author has worked for 20 years, and where we were able to obtain full access to university administrators and English teachers. As a mid-ranking university in Beijing (ranking 30 among 66 universities in the city), BISTU has allowed some relatively cautious reforms to College English, with some schools having the length of College English courses reduced.

\section{Data collection}

Data was collected in 2018, one year after the GCET was officially issued. We conducted individual interviews in Chinese with the president, the provost, and school deans of Science, Arts and Business in BISTU, for 40-60 minutes each. All interviews were recorded and transcribed. In addition, 76 English teachers were included in this investigation, all from the School of Foreign Studies in BISTU, by questionnaire and interview. In our discussion of the interviews, we focus on 
the views of two teachers.

The questionnaire, conducted in Chinese, was composed of three parts. The first part asked for background information about gender, age and academic position. The second part was composed of four 5-point Likert scale questions. To get English teachers' real attitudes towards the change in the status of College English in the GCET, we asked the questions from different perspectives. The third part was an open question asking for teachers' comment on the GCET. After the pilot study, the questionnaire was revised, uploaded to "wenjuanxing" (Questionnaire Star), and then delivered via mobile phone to WeChat groups. The teachers in the group filled in their answers on their mobile phones, and data were analyzed automatically by "wenjuanxing". To make the Chinese questionnaire readable in this paper, we have translated it into English (see Appendix).

\section{Main findings}

Policy makers: Ministry of Education (MOE) in China and distinguished scholars

As national LEP, both the CECR and GCET are enacted normally after several rounds of negotiation between senior officials in the MOE and distinguished scholars in some public universities. To investigate the changes in the policy makers' attitudes towards the status of College English, we compared the texts of the CECR and GCET from the perspective of title, value and target learners, as is shown in table 1 .

Table 1. Comparison between the CECR and GCET

\begin{tabular}{|c|c|c|}
\hline Value & \multicolumn{1}{|c|}{ CECR (2007) } & \multicolumn{1}{c|}{ GCET (2017) } \\
\hline Not mentioned & $\begin{array}{l}\text { To satisfy the demands of national } \\
\text { development, and a variety of short and long- } \\
\text { term prospective needs of students. }\end{array}$ \\
\hline learnet & $\begin{array}{l}\text { As a compulsory course for all } \\
\text { College students, the CECR } \\
\text { proposed to grant enough hours and } \\
\text { credits at every university. As much as } \\
10 \% \text { of all credits (about 16 credits) is } \\
\text { recommended. }\end{array}$ & $\begin{array}{l}\text { As a most important course in tertiary foreign } \\
\text { language education, College English is } \\
\text { proposed as a compulsory course for the } \\
\text { majority of non-English majors. In } \\
\text { addition, every university has the right to } \\
\text { make its own arrangements. }\end{array}$ \\
\hline
\end{tabular}

Firstly, the change in title, from "Requirement" (College English Curriculum Requirement)" to "Guidelines" (Guidelines on College English Teaching), is a sign of voluntary relinquishment of governmental power in LPP at the macro level, which is not very common in a centralized education system like China's. Wang Shouren, a representative of scholars in drafting and enacting these two documents, explains: Compared with "Requirement", "Guidelines" indicates the ideology of the government has changed, i.e. bottom-up diversity is becoming a target for College English education to strive for (Wang, 2015). Consequently, universities are granted more autonomous power to develop their own individualized and targeted College English teaching (Wang, 2016).

Secondly, there is a new emphasis on the value of College English. In the GCET, a detailed preface is added to state the value of College English. Apart from the function of satisfying a variety of demands mentioned in table 1, the preface also mentions that "in the global age, English is the most widely used language. It is an important tool for international communication and technology 
development. So, College English is of high necessity for tertiary education". Wang (2016) explains that the reason why the GCET has the value of College English stated explicitly is to respond to the widespread doubt and questioning around the predominant status of College English by emphasizing the significance and function of College English to national, and the students', overall development.

Thirdly, there is a change in the learners targeted. In contrast to the CECR, in which College English is proposed as a compulsory course for all College students, the GCET allows a minority of students not to learn College English. According to Wang (2016), the majority of non-English majors are encouraged to learn English, and a small number can choose to learn less or not learn English at all. They can choose other foreign languages such as Japanese, Dutch, French or Spanish.

Comparing the difference between the two documents on College English, we can see clearly that the MOE is faced with a dilemma about how to position College English. On the one hand, without English as an indispensable bridge to the rest of the world, China could not have developed so rapidly and benefited so enormously from global participation both in the economy and in technology. On the other hand, growing apprehension about the status of the Chinese language and culture, together with the low efficiency of College English education, forced the MOE to reflect seriously on the feasibility of its former ambitious policy which proposed College English as a compulsory course for all non-English majors, and the resulting potentially negative impact of English mania on Chinese culture. Just as the former Minister of Education used to contend, "we must correct the phenomenon of preferring foreign language to mother language, we must guide and urge the teaching and usage of our own language" (Yuan, 2005). Therefore, the MOE has to make a compromise by slightly and cautiously lowering the status of College English in a symbolic way and giving the grassroots more opportunities to make their own choice at the local level.

In our investigation, different groups of individuals all appreciated the GCET's move to grant autonomous power to universities. However, different attitudes, interpretations and reactions still arose regarding the change in the status of College English in the GCET.

\section{People with expertise}

The dominant status of College English in the Chinese education system has not received much attention from people with expertise except for a handful who have raised questions from the perspective of social demands and potential cultural erosion (e.g. Lu, 2014; Wang, 2013; Wei \& Su, 2011). Some of them attribute the laissez-faire development of English to the lack of specific institutions majoring in language planning and administration (e.g. Cai, 2011; Hu, 2009; Zhao, 2014). As to the change in the status of College English in the GCET, only a few people with expertise have commented in relevant academic journals.

Among them, Cheng (2014) expressed his concern when the GCET was drafted. He contended that if the MOE stopped supporting English as a mandatory course for all students, the government would not invest enough in English education. Then families who are not in good economic and educational circumstances would not be able to afford adequate English education for their children. Consequently, more social inequity would ensue. Cai (2017) expressed disapproval of the GCET from the perspective of national demands. He argued that English education in Mainland China is not successful enough to provide students with sufficient proficiency to satisfy national development needs. In addition, as the only foreign language available for most Chinese to learn, English is a precious channel for Chinese people to get access to the world outside China. Therefore, 
it is inappropriate for the GCET to lower the status of College English.

Shu (2015, p. 2) openly expressed his dissatisfaction with other experts: "while there is no specific institution majoring in language planning and policy in China, our foreign language teaching and research circle should have taken up more responsibility and provided scientific theory and grounded investigation. But people in this circle are so indifferent to it that they even display collective aphasia in front of major LPP events. This causes people with expertise to fail to have an effective impact on LPP".

On the whole, the experts' overall concern with LPP status planning and its social consequence is very limited, and as a result, their influence on LPP is also limited in China compared with other forces.

\section{People with influence in society}

In some sense, the lowered status of College English in the GCET is the result of persistent appeals from people with influence in society. Some distinguished scholars persistently commented in influential mainstream media that the English proficiency of Chinese students remains constantly low, despite great sacrificing of other courses. They advocated abolishing the policy of forcing everyone to learn English, giving young people more time to develop their own interests (e.g. Fang 2011; Niu, 2009; Jiang, 2010; Yuan, 2004; Zhang, 2005). In regard to this criticism, a survey carried out by the foreign language education research center in Beijing Foreign Studies University provided strong evidence: most of the spare time of Chinese non-English majors is actually spent studying English, but the test-oriented English they learn in school cannot be applied in real life and work (Ruan, 2009).

Since it is required that all people wishing to be promoted in the workplace must take English tests, which promotes the dominant status of English as a compulsory course in school (Yang \& Gui, 2007), the appeal to abolish English tests in the workplace has long been advocated by scholars and the general public (e.g. Li, 2015; Lu, 2012, p. 195; Yang \& Gui, 2007). On March 21. 2013, Zhang Shuhua, a representative of the People's Congress, declared: "the overemphasizing of English in education and profession evaluation is getting this nation bogged down in a self-torturing and selfentertaining mud" ( $\mathrm{Li}, 2013)$. On March 8. 2016, Tencent news publicized a remark from another representative of the People's Congress, Chen Zemin, who publicly questioned the necessity and effects of English testing in the workplace: "professional position is the symbol of academic level and professional quality, it should not be evaluated by English. Besides, English is not indispensable in some fields, so it's a huge waste of time and energy to learn English. Consequently, English testing should be cancelled" (Kang, 2016).

Later, the document Opinions on Deepening the Reform of Talent Development Mechanism was issued by the Central Committee of the Communist Party of China in 2016, declaring explicitly that the government would rescind the regulations on mandatory English testing in the workplace, and employers and institutions would have the right to make their own policy. Since then, English testing in the workplace has gradually been abolished in several regions of China. There is no doubt that people with influence in society played an important role in effecting national language education policy through the GCET in lowering the status of College English.

\section{People with power at meso level}

Normally, the education program for all university students is designed within the schools they study 
and negotiated among the school deans, the president and the provost of the university. As a basic course for university students, College English has its status, target and length mainly decided by the deans of the various schools, with the president and the provost intervening when necessary. While many universities have already had the length of College English courses reduced, the president and the provost of BISTU did not totally agree with this reform. Together with the deans in the Arts and Business schools, they insisted that College English should still be a compulsory course for all non-English majors. It should last two full years, with General English in the first year focusing on language skills to help students pass CET-4, followed by extended courses in year two, with students choosing from a variety of courses including intercultural communication, academic English, CET-6/TOEFL (Test of English as a Foreign Language)/IELTS (the International English Language Testing System) course, and oral English. As to the determined and persistent plea from the deans of the Schools of Computer Science \& Technology (SCST) and the School of Telecom \& Communication (STC) to reduce the length of College English, after several months of negotiation with these deans, the president and the provost of BISTU finally made a compromise and reluctantly agreed to their request.

Like most leaders in polytechnic universities, the president and the provost in BISTU are scholars with backgrounds in science. In our interviews, they were very careful with their words and logical in their thinking. They admit that they did not know much about the details of the GCET, but they appreciated the more autonomous rights granted to universities. When asked opinions about the GCET's recommendation that a small number of non-English majors could be exempt from College English, they all showed disapproval and stated explicitly that they had no motivation to lower the present status of College English as compulsory for all. On the contrary, the president even emphasized the importance of College English:

College English is a fundamental course for the internationalization of our university. Its status as a compulsory course could not be lowered. What's more, College English should be strengthened so as to provide a solid basis for students' further professional development.

The provost was quite concerned with the change in the status of College English in the GCET:

In this global age, every student should be equipped with basic English language skills and communicative ability. Our university is not a first-class university and our students are not excellent enough in English to say they do not have to learn College English. Besides, from the perspective of administration, if we allow some students to be exempt from College English classes, what will they do in bilingual instruction class?

The deans of Arts and Business all emphasized the value of College English and hoped the efficiency and effectiveness of College English could be improved so as to build a more solid basis for further bilingual instruction. Bilingual instruction is also called English as Medium of Instruction (EMI) in China. To strengthen international cooperation and keep up with the latest technological development, in 2001 the MOE issued an ambitious policy named Guideline for Improving the Quality of Undergraduate Teaching to promote EMI. Although faced with heated controversy, EMI seems to be increasingly popular and feasible in many universities in China with the quality of teaching staff improving.

Although all the administrators in BISTU agreed that College English should remain as a compulsory course for all non-English majors, the deans of the Science schools showed a strong determination to reduce credits and the length of College English. The dean of SCST said:

From the perspective of professional development, English is an indispensable skill for everyone in this 
global age. But the thing is, since the students in our school are excellent enough to learn their professional knowledge via EMI directly, what's the sense of keeping College English for two full years?

From the interview with this dean, we can see that his motivation for cutting the course length of College English was not to lower the status of English. On the contrary, most of the deans of the Science schools have backgrounds in overseas study and regard English as a basic and indispensable tool to communicate in a global age. The dean of SCET was making the point that now that students' English proficiency is good enough to learn professional knowledge via EMI, the mission of College English is supposed to come to an end. The dean of Automation Engineering expressed a similar idea:

The majority of the latest information in technology is delivered in English, so reading English literature and taking notes in English lectures are all very important skills for Science majors. What we should think now is how to improve students' English skills effectively, not how high the status of College English should be.

Although very few top universities (e.g. Tongji University and Tsinghua University) allow College English to be an optional course, and approximately $50 \%$ of universities in China have reduced the length of College English from two full years to one and a half years or even shorter (Cai, 2012), as far as we know, the vast majority of universities in China have no intention of converting College English from a compulsory course to an optional one, and do not allow any nonEnglish majors to be exempted from College English, despite the approval of the GCET. English skill training in College English is even emphasized and regarded as an indispensable basis for EMI in different universities, and BISTU is not an exception. Almost all the school deans in BISTU complained that the inadequate English proficiency of university students is the greatest barrier for the implementation of EMI. This shows that the dominant status of English has not in fact been lowered. Instead, it has been strengthened in higher education in China, but with College English gradually transferring from the leading role to a supporting role in EMI.

\section{People as implementers and micro policy makers}

The attitudes and reactions of College English teachers in BISTU to the change in the status of College English in the GCET were collected by means of a questionnaire (see Appendix).

\section{Result of the questionnaire}

The questionnaire asked whether respondents agreed with four statements regarding retaining or abolishing College English (see Appendix for the wording of the statements). Table 2 shows their responses.

Table 2. Teachers' attitudes towards the change in status of College English in the GCET

\begin{tabular}{|l|l|l|l|l|l|l|l|}
\hline & Mean & $\begin{array}{l}\text { Standard } \\
\text { deviation }\end{array}$ & $\begin{array}{l}\text { Strongly } \\
\text { disagree } \\
(\%)\end{array}$ & $\begin{array}{l}\text { Disagree } \\
(\%)\end{array}$ & $\begin{array}{l}\text { Not } \\
\text { sure } \\
(\%)\end{array}$ & $\begin{array}{l}\text { Agree } \\
(\%)\end{array}$ & $\begin{array}{l}\text { Strongly } \\
\text { agree }(\%)\end{array}$ \\
\hline Q 1 & 3.079 & 0.740 & 0.0 & 40.8 & 26.3 & 32.9 & 0.0 \\
\hline Q 2 & 3.592 & 0.885 & 9.2 & 63.2 & 5.3 & 22.4 & 0.0 \\
\hline Q 3 & 3.552 & 0.677 & 1.3 & 72.4 & 6.6 & 19.7 & 0.0 \\
\hline Q 4 & 3.684 & 0.726 & 3.9 & 78.9 & 1.3 & 13.2 & 2.6 \\
\hline
\end{tabular}

Questions 2, 3 and 4 asked whether College English should be abolished as a compulsory course, 
remain compulsory, or become optional, respectively. The results showed that more than $70 \%$ of English teachers did not totally approve of the GCET's lowering the status of College English. Instead, they insisted that College English should be a compulsory course for all non-English majors, although they were not too confident that College English was indispensable and valuable for all non-English majors (question 1).

Below are some of the teachers' responses to the open question: What's your comment on the change in the status of College English in the GCET?

Teacher A: It sounds reasonable. But how to judge who should be exempt from College English?

Teacher B: No, it is not practical! What are the criteria to judge who can quit College English?

Students with too good English or too poor English? Demand or interest?

Teacher C: I do think most students need to learn English, but who should learn and when and for how long, as well as what types of English, College English or Academic English or EMI, should be decided by the schools they study in, not us, not the MOE!

Teacher D: Does it mean a minority of students do not have to learn College English? Surely it is ok for those with pretty good English, but as to the poor English learners, College English is a course they must learn to pass CET-4.

Teacher E: I think it depends. As the customers of education, students have the right to choose their course.

Together with other responses to the open question, we can see what many teachers were concerned about is the implementation of the GCET, i.e. how to judge who could be exempt from College English. In fact, the opinion that "College English is recommended as a compulsory course for the majority of non-English majors" expressed an attitude which implied that universities do have the autonomy to make bottom-up decisions on the status of College English. However, the College English teachers in BISTU seemed to prefer explicit top-down instruction to make the implementation of the policy easy and simple.

\section{Result of the interviews}

We then interviewed two College English teachers, T. Wang and T. Wu (pseudonyms), about their attitudes towards the change in status of College English in the GCET. T. Wang supported the document whereas the T. Wu expressed her apprehension. T. Wang said:

Our students have been adults, they do have the basic right to choose what they want to learn. GCET is right in giving choices to students, even just a small number! Our human resources are precious and limited, why do we waste them on the people who do not need or have no interest at all. Besides, College English education will never have any improvement without the threat of degrading to optional one.

By contrast, $\mathrm{T}$. Wu expressed a different opinion:

I do not think it is a good idea to give some students the right to quit studying College English. I am sure if this happens, other students will be influenced and the overall students' passion for English will definitely drop as well as their English proficiency. These students have no social experience and thirst for knowledge; they will never understand the importance of English to their horizons and professional development.

Combining the results of the questionnaires and interviews, we found that most College English teachers in BISTU did not totally approve of the GCET's lowering the status of College English, 
although they were not too confident about the efficiency and effectiveness of College English in improving students' English proficiency. In addition, the reason many teachers disapproved of the GCET seemed not to be its rationale but their uncertainty about the feasibility of policy implementation and doubt about students' awareness of the value of College English. When faced with status planning, they were more likely to regard themselves as policy implementers rather than micro policy makers.

\section{Discussion and Conclusion}

This study applied the categories proposed by Zhao \& Baldauf (2012) and Wiley \& Garcia (2016) to investigate multiple levels of individual agency in the change in the status of College English in the GCET in China. The key findings of this study are as follows:

The discourse around the GCET reflects the ideological stance of the MOE. By deliberately lowering the aggressive status of College English in a symbolic way and giving the universities more opportunities to make bottom-up choices, the MOE is, in a cautious way, beginning to strengthen the protection of Chinese culture and preventing the unrestricted development of English. Contrary to the expectations of the MOE and the people with influence in society, who intended to slightly weaken the predominant role of English through abolishing the mandatory requirement for all non-English majors, the status of English in BISTU has not in fact been lowered. Instead, it has improved and even been emphasized more in practice. To our knowledge, the vast majority of universities in China have no intention of converting College English into an optional course or exempting some students from studying it, because College English is regarded as the basic course for EMI. Now that universities are given greater autonomous power to carry out English education planning, it is these meso-level individuals who spare no effort to strengthen the dominant status of English in practice by way of emphasizing EMI. As EMI programs do not enjoy legal protection in China, the fact they are flourishing is indicative of an educational decentralization process that has been happening in China (Gao \& Wang, 2017, p. 226).

However, the individual groups who should have produced a more marked agency in LPP are people with expertise. Their overall indifference to social reality and empirical study to a large extent limits their impact on status planning in China. In addition, the low efficiency and effectiveness of English education has existed for 40 years, and it is the basic reason for widespread dissatisfaction with the status of College English. People with expertise should have contributed more in this respect.

Similarly, as the front line in English education, teacher agency needs to be strengthened. Compared with other language policy research in which teacher agency has been highlighted as a significant role in interpreting, negotiating, resisting and (re)creating language policy, status planning is usually regarded as a macro-level top-down political issue in a highly centralized education system such as China's. English teachers in BISTU inadvertently position themselves as mere policy implementers, expressing their disapproval of the GCET not because of the rationale of the policy itself but mainly because of the difficulty of implementing it. This is exemplified in what M. Li (2010) has contended, that English teachers in China are regarded as not yet able to play a role in education policymaking. They prefer to execute top-down orders and follow the syllabus 
mechanically, uninvolved in anything other than teaching (Zhou \& Zhu, 2016).

Finally, through analyzing multiple layers of individual agency, we hope to offer a better understanding of the beliefs and attitudes from policy makers to different individual groups at macro, meso and micro levels, and explore "who" has "how much" impact in reactions to the change in LPP in China. Although different individuals respond differently towards the GCET, it is people with influence in society who have an obvious impact on the macro-level policy making. In addition, through illustrating how BISTU administrators wield a disproportionate amount of power in the way they interpret or even ignore top-down language policy, this study reveals that university administrators are the de facto arbiters in meso-level policy making. We contend that the most fundamental challenge for College English in China is its low efficiency and effectiveness in improving English learners' proficiency. This is the area in which people with expertise and English teachers should have contributed more $(\mathrm{Hu}, 2017 ; \mathrm{Li}, 2017)$ in order to exert more influence in LPP.

Our findings have indicated that multiple layers of individuals exert very different impacts on LPP making and implementation, and further research is needed to focus on the group of people who constitute the largest number of English learners in the world: university students in China. Compared with policy makers and implementers, Chinese students have not received enough attention in LPP research. As receivers of language education and final evaluators of LPP, learners as key actors in LPP deserve more attention.

\section{Note}

This article was supported by the China Scholarship Council (CSC) and BISTU's Key Cultivation Projects for Research (Grant No. 5221823805).

\section{Notes on contributors}

Jingyan Cheng works as an Associate Professor at Foreign Language Studies in Beijing Information Science and Technology university. Her current interest area includes language education policy and intercultural communication. She currently visits Institute of Education, University College London as Honorary Research Associate.

Li Wei is Chair of Centre for Applied Linguistics, Institute of Education, University College London. His research interests include translanguage, family language policy and early childhood bilingualism.

\section{References}

Aizawa, I., \& Rose, H. (2018). An analysis of Japan's English as medium of instruction initiatives within higher education: The gap between meso-level policy and micro-level practice. Higher Education, 77(6), 1125-1142. doi:10.1007/S10734-018-0323-5

Baldauf, R. B. (2006). Rearticulating the case for micro language Planning in a Language Ecology Context. Current Issues in Language Planning, 7(2-3), 147-170. doi:10.2167/cilp092.0

Baldauf, R. B. (2008) Rearticulating the case for micro language planning in a language ecology context. In A. J. Liddicoat \& R. B. Baldauf (Eds.), Language planning and policy: Language planning in local contexts (pp. 18-41). Clevedon: Multilingual Matters.

Baldauf, R. B., \& Kaplan, R. B. (2003). Language policy decision and power: who are the actors? In P. M. Ryan \& R. Terborg (Eds.), Language issues of inequality (pp.19-39). Mexico City: 
Universidal Nacional Autonoma de Mexco.

Cai, J. G. (2012). Analysis on the reasons and trends of the disappearance of College English in China. Foreign Language Research, (3), 46-52.

Cai, J. G. (2017). Review of Chinese tertiary English education: failure and lessons. Journal of Northeast Normal University (Philosophy and Social Sciences), (5), 1-7.

Cai, Y. L. (2011). Some thoughts on the national language strategy of China. Foreign Language World, (1), 8- 15.

Canagarajah, S. (2005). Reclaiming the Local in Language Policy and Practice. Mahwah, NJ: Lawrence Erlbaum.

Canagarajah, S. (2012). Teacher development in a globalized profession: An autoethnography. TESOL Quarterly, 46 (2), 258-279. doi:10.1002/tesq.18

Cheng, J. Y. (2015). The current research and trend of foreign language policy and planning in China. Foreign Language Education, 36(5), 69-72

Cheng, X. T. (2014). Some thoughts on the changes in English education policies. Curriculum, Teaching Material and Method, (5), 58-64.

Cooper, R. L. (1989). Language Planning and Social Change. Cambridge: Cambridge University Press.

Davis, A. K., \& Phyak, P. (2017). Engaged Language Policy and Practice. New York: Routledge.

EF English Proficiency Index (2018). https://liuxue.ef.com.cn/epi/.

Fang, Y. J. (2011). Riyu xiandaihua chengjiu riben xiandaihua de qishi - jiantan woguo quanmin xueyingyu de xianxiang (The contribution of Japanese modernization to Japan modernization --- an inspiration to the phenomenon of "everyone learns English" in China). Journal of The Chinese Society of Education, (7), 17-21.

Feng, A. (2009). English in China: Convergence and divergence in policy and practice. AILA Review, $22,85-102$.

Fishman, J. A. (1973). Language modernization and planning in comparison with other types of national modernization and planning. Language in Society, 2(1), 23-43.

Gao, X. A., \& Wang, W. (2017). Bilingual education in the People's Republic of China. In O. Garcia, A. Lin, S. May (Eds.), Bilingual and multilingual education (pp. 219-231). Switzerland: Springer.

Garcia, O., \& Menken, K. (2010). Stirring the onion: Educators and the dynamics of language education policies (looking ahead). In K. Menken \& O. Garcia (Eds.), Negotiating language policies in schools: Educators as policy makers (pp. 246-261). New York: Routledge.

Gil, J. (2016). English language education policies in the People's Republic of China. In A. Kirkpatrik (Ed.), English language education policy in Asia (pp. 49-90). Switzerland: Springer.

Gil, J., \& Adamson, B. (2011). The English language in mainland China: A sociolinguistic profile. In A. Feng (Ed.), English language education across Greater China (pp. 23-45). Bristol, UK: Multilingual Matters.

Hao, T. (2018). Teacher agency in times of educational change: The case of transitioned teachers in Vietnam. Current Issues in Language Planning, 20(5), 544-559. doi:10.1080/14664208.2018. 1553912.

Harklau, L., \& Yang, A. H. (2019). Educators' construction of mainstreaming policy for English learners: A decision-making theory perspective. Language Policy, 1-24. doi.org/10.1007/ s10993-019-09511-6

Hornberger, H. N. (2006). Frameworks and models in language policy and planning. In T. Ricento 
(Ed.), An introduction to language policy: Theory and method (pp. 24-41). Malden, MA: Blackwell.

Hornberger, H. N., \& Johnson, C. D. (2007). Slicing the onion ethnographically: Layers and spaces in multilingual language education policy and practice. TESOL Quarterly, 41(3), 509-532.

$\mathrm{Hu}, \mathrm{P}$. (2017). Some thoughts on the Way-Out for College English teachers in transition period. Advances in English, 7(1), 42-48.

$\mathrm{Hu}, \mathrm{W}$. Z. (2009). The strengths and weaknesses of China's foreign language education in the past 60 years. Foreign Language Teaching and Research, (3), 163-169.

$\mathrm{Hu}$, Y. (2007). China' foreign language policy on primary English education: What's behind it? Language Policy, 6, 359-376.

Hult, F. (2014). How does policy influence language in education? In R. E. Silver \& S. M. Lwin (Eds.), Language in education: Social implications (pp. 159-175). London: Continuum.

Hult, F. (2017). Discursive approaches to language policy. In S. E. F. Wortham, D. Kim, \& S. May (Eds.), Discourse and education (pp.111-121). New York: Springer.

Hult, F. (2018). Foreign language education policy on the horizon. Foreign Language Annals, 51(1), 35-45. doi: 10.1111/flan.12315

Jernudd, B. H. (1973). Language planning as a type of language treatment. In J. Rubin \& R. Shuy (Eds.), Language planning: current issues and research (pp.11-23). Washington, D. C.: Georgetown University Press.

Jiang, G. Y. (2010). English Education in China: From Economic Perspective. Xiamen: Xiamen University Press.

Johnson, C. D. (2013). Positioning the language policy arbiter: Governmentality and footing in the school district of Philadelphia. In J. Tollefson (Ed.), Language policies in education: Critical issues ( $\left.2^{\text {nd }} \mathrm{ed}, \mathrm{pp} .116-135\right)$. New York: Routledge.

Johnson, C. D. (2018). Teachers' language policy engagement: European perspectives and challenges. Language and Education, 32(5), 462-469. doi:10.1080/09500782.2018.1485694

Johnson, C. D., \& Johnson, J. E. (2015). Power and agency in language policy appropriation. Language Policy, 14, 221-243. doi:10.1007/s10993-014-9333-z

Kang, Y. (2016). Quanguo rendadaibiao Chen Zemin jianyi quxiao quanguo zhicheng waiyu he jisuanji kaoshi (On the proposal contended by Chen Zemin, a representative of NPC: cancelling English and computer as compulsory tests for professional position). Pengpai News, 08-03.

Kaplan, R. B., \& Baldauf, R. B. (1997). Language Planning: From Practice to Theory. Clevedon, UK: Multilingual Matters.

Kaplan, R. B., \& Baldauf, R. B. (2003). Language and Language-in-education Planning in the Pacific Basin. Dordrecht, Netherlands: Kluwer.

Li, G. W. (2013). Zhang Shuhua: "yingyu re” haofei daliang jiaoyuziyuan (Zhang Shuhua: "English mania" and its excessive consumption of education resources). China Today, 11-03.

Li, M. L. (2010). EFL teachers and English language education in the PRC: Are they the policy makers? The Asia-Pacific Education Researcher, 19(3), 439-451.

Li, X. (2015). Shixi woguo gaoxiao daxueyingyuyuke bixiu de yuanyin ---jianping "guodu”yingyu jiaoyu de yingxiang (On the status of College English as compulsory course and influence of “over" English Education). Journal of Management Sciences, (8), 102-104.

Li, Y. M. (2010). Some Thoughts on Foreign Language Planning in China. The Journal of Foreign Languages, (1), $2-7$. 
Li, Y. M. (2017). Tigao guojia waiyu nengli renzhong er daoyuan (Long journey to improve national foreign language proficiency). People's Daily, 02-06.

Li, Y.Z. (2016). The evolution and significance of the concept of language policy in Chinese context. Foreign Language Research, (3), 15-19.

Liddicoat, A. J. (2014). The interface between macro and micro-level language policy and the place of language pedagogies. International Journal of Pedagogies and Learning, 9(2), 118-129. doi: 10.1080/18334105.2014.11082025

Liddicoat, A. J. (2019). Constraints on agency in micro-language policy and planning in schools: A case study of curriculum change. In J. Bouchard \& G. P. Glasgow (Eds.), Agency in language policy and planning: Critical inquiries (pp. 149-170). New York \& London: Routledge.

Liddicoat, A. J., \& Baldauf, R. B. (2008). Language planning in local contexts: Agents contexts and interaction. In A. J. Liddicoat \& R. B. Baldauf (Eds.), Language planning and policy: Language planning in local contexts (pp. 3-17). Clevedon, UK: Multilingual Matters.

Liddicoat, A. J., \& Taylor-Leech, K. (2014). Micro language planning for multilingual education: Agency in local contexts. Current Issues in Language Planning, 15(3), 237-244. doi:10.1080/ 14664208.2014 .915454

Lu, Z. W. (2003). An analysis of China's foreign language policies and tentative suggestions. Journal of Basic English Education, 16(1), 6-12.

Lu, Z. W. (2012). Foreign Language Policy. Beijing: Beijing University Press.

Lu, Z. W. (2014). Reform focuses of foreign-language education in contemporary China. Journal of Yunnan Normal University (Humanities and Social Sciences), (1), 8-14.

Miranda, N., Berdugo, M., \& Tejada, H. (2016). Conflicting views on language policy and planning at a Colombian university. Current Issues in Language Planning, 17(3-4), 422-440. doi:10.1080/ 14664208.2016.1204052

Nguyen, H., \& Bui, T. (2016). Teachers' agency and the enactment of educational reform in Vietnam. Current Issues in Language Planning, 17(1), 88-105. doi:10.1080/4664208

Niu, W. X. (2009). Waiyure gai jiangwen le (Foreign Language Fever Should be Cooled Down Now). Eunited, 03-24.

Pinto, S., \& Araújo e Sá, M. H. (2019). Language education policy in Portuguese public universities: the voices of institutional stakeholders. Current Issues in Language Planning, 20(2), 140-159. doi:10.1080/14664208.2018.1468962

Ramanathan, V. (2005). Rethinking language planning and policy form the ground up: Refashioning institutional realities and human lives. Current Issues in Language Planning, 6(2), 89-101. doi: 10.1080/14664200508668275

Ricento, T. K. (2000). Historical and theoretical perspectives in language policy and planning. Journal of Sociolinguistics, 4(2), 196-213. doi:10.1111/1467-9481.00111

Ricento, T. K., \& Hornberger, N. H. (1996). Unpeeling the onion: Language planning and policy and the ELT professional. TESOL Quarterly, 30(3), 401-27.

Rubin, J., \& Jernudd, B. (1971). Can Language Be Planned? Sociolinguistic Theory and Practice for Developing Nations. Honolulu: University Press of Hawaii.

Ruan, W. (2009). The irrational English-learning frenzy must be cooled down. Journal of Shenzhen University (Humanities and Social Sciences), (2), 157-160.

Shao, Q., \& Gao, X. A. (2019). Protecting language or promoting dis-citizenship? A post-structural 
policy analysis of the Shanghainese Heritage Project. International Journal of Bilingual Education and Bilingualism, 22(3), 352-364. doi: 10.1080/13670050.2018.1451482

Shohamy, E. (2010). Case of language policy resistance in Israel's centralized educational system. In K. Menken \& O. Garcia (Eds.), Negotiating language policies in school (pp.182-197). New York: Routledge.

Shu, D. F. (2015). Foreign language academic research should adapt to national development strategies and meet social needs. Foreign Language Learning Theory and Practice, (3), 1-5.

Soler, J., \& Vihman, V. A. (2017). Language ideology and language planning in Estonian higher education: Nationalizing and globalizing discourses. Current Issues in Language Planning, 19(1), 1-20. doi:10.1080/14664208.2017.1281039

Tollefson, J. W. (2002). Limitations of language policy and planning. In R. Kaplan (Ed.), The Oxford handbook of Applied Linguistics (pp. 415-423). New York: Oxford University Press.

Wang, Y. Q. (2013). Reflections on the major problems in China's foreign language education from the perspective of national strategy. Foreign language in China, (2), 13-24.

Wang, S. R. (2015). Individualized English language teaching in the context of contemporary China: Notions and practice. Foreign Languages and Their Teaching, (4), 1-4.

Wang, S. R. (2016). An interpretation of the Guidelines on College English Teaching. Foreign Language World, (3), 2-10.

Wei, R. N., \& Su, J. Z. (2011). Foreign language use in metropolises: an analysis of evidence from a national survey with special references to Beijing, Shanghai, Tianjin, Guangzhou, Shenzhen, Chongqing and Dalian. Foreign Language Teaching and Research, (6), 924-933.

Wiley, G. T., \& Garcia, O. (2016). Language policy and planning in language education: Legacies, consequences, and possibilities. The Modern Language Journal, 100 (supplement), 48-63. doi: $10.1111 /$ modl. 12303

Yan, C. (2012). 'We can only change in a small way': A study of secondary English teachers' implementation of curriculum reform in China. Journal of Educational Change, 13, 431-437. doi: 10.1007/s10833-012-9186-1

Yang, H. \& Gui, S. (2007). The sociology of language testing. Modern Foreign Language, (4), 368-374.

Yuan, J. W. (2004). Yingyu shifou neng jianggewei xuanxiiuke (Can English be degraded to elective course?). China Information News, 10-01.

Yuan, G. R. (2005). Shuli he luoshi kexue fazhanguan, cujing yuyanwenzi gongzuode xietiao kechixu fazhan (Establish and Implement the Scientific Development Concept, Promote the Coordination and Sustainable Development of Language and Writing Work) (Speech at the 2005 Annual Language Work Conference). Retrieved from http://www.moe.edu.cn/publicfiles/ business/htmlfiles/moe/s6152/201202/129823.html, 09-15

Zhang, L. X. (2005). Benmo daozhide "qiangshi yingyu" ("Strong English" with wrong status). Chongqing Daily, 08-09.

Zhao, R. H. (2014). Foreign language planning and policy in China: essential problems. Journal of Yunnan Normal University (Humanities and Social Sciences), (1), 1-7.

Zhao, S. H. (2011). Actors in language planning. In E. Hinkel (Ed.), Handbook of research in second language teaching and learning (pp. 905-920). Routledge Handbooks Online.

Zhao, S. H., \& Baldauf, R. B. (2012). Individual agency in language planning: Chinese script reform as a case study. Language Problems \& Language Planning, 36(1), 1-24. 
Zheng, X., \& Davison, C. (2008). Changing pedagogy: Analyzing ELT teachers in China. London: Continuum.

Zhou, X., \& Zhu, X. (2016). Standards-driven College English curriculum implementation and evaluation. Foreign Language Learning Theory and Practice, (3), 32-37.

Zhu, H., \& Li, W. (2014, Spring). Geopolitics and the changing hierarchies of the Chinese language: Implications for policy and practice of Chinese language teaching in Britain. Modern Language Journal, 98(1), 326-339.

\section{Appendix:}

\section{Questionnaire for College English Teachers' attitudes and reactions to the GCET}

To collect College English teachers' opinions about the changes in the status of College English in Guidelines on College English Teaching, we invite you to fill in this questionnaire anonymously. There is no right or wrong answer, and the data is only used for statistics analysis! Thanks!

I. Please tick " $\sqrt{ }$ " the answer(s) that fit(s) you.
1. Gender:
A. Male
B. Female
2. Age:
A. $25-30$
B. $31-40$
C. $41-50$
D. $51-60$

3. Academic position:
A. assistant professor
B. lecturer
C. associate professor
D. professor

II. Do you agree with the following the statements? Please choose:

1. College English is an indispensable course for all students.
A. strongly agree
B. agree
C. not sure
D. disagree
E. strongly disagree

2. The policy of College English as a compulsory course for everyone should be abolished.
A. strongly agree
B. agree
C. not sure
D. disagree
E. strongly disagree

3. I support the current policy of compulsory College English education in university.
A. strongly agree
B. agree
C. not sure
D. disagree
E. strongly disagree

4. College English should be an optional course.
A. strongly agree
B. agree
C. not sure
D. disagree
E. strongly disagree

III. Open question.

What's your comment on the change in the status of College English in the GCET? 